\title{
Identifikasi Kualitas Beras dengan Citra Digital
}

\author{
Arissa Aprilia Nurcahyani ${ }^{1}$, Ristu Saptono ${ }^{2}$ \\ 1,2Program Studi Informatika, FMIPA, Universitas Sebelas Maret \\ Email: ${ }^{1}$ arissa@student.uns.ac.id, ${ }^{2}$ ristu.saptono@staff.uns.ac.id
}

\begin{abstract}
Abstrak
Beras merupakan makanan pokok yang paling banyak di konsumsi oleh masyarakat Indonesia. Namun, harga beras di pasaran justru semakin melonjak, sehingga banyak beredar beras yang memiliki kualitas kurang baik. Oleh karena itu perlu adanya standar kualitas mutu dari pihak gudang beras saat mendistribusikan beras ke pasaran. Standar pengujian kualitas dari pihak Bulog terdapat dua tahap, yaitu uji laboratorium dan uji visual. Namun, pengujian secara visual selama ini masih dilakukan secara manual sehingga masih sering terjadi kesalahan karena terbatasnya penglihatan manusia dan subjektivitas penguji. Oleh karena itu, sistem pengujian secara visual dengan citra digital dapat menjadi solusi yang efektif untuk permasalahan tersebut. Proses pengujian dapat dilihat dari nilai putih, nilai bersih, dan nilai utuh beras yang diakuisisi melalui pengolahan citra digital. Proses akuisisi nilai bersih dan putih dilakukan dengan menganalisis nilai HSV (Hue, Saturation, Value), sedangkan nilai utuh dilakukan dengan menganalisis luas region area objek. Sebelumnya, dilakukan training terhadap 30 data untuk mendapatkan decision tree dengan model ID3 (Iterative Dichotomiser Tree). Data yang telah diakuisisi kemudian diklasifikasi ke dalam 3 kelas yaitu baik, kurang dan buruk dengan menggunankan aturan dari decision tree yang dihasilkan pada proses training. Hasil pengujian dengan metode $k$-fold cross validation dengan $\mathrm{k}=5$ didapatkan akurasi sebesar $96.67 \%$.
\end{abstract}

Kata Kunci: Pengolahan citra, Beras, Decision tree, ID3, Sistem pakar

\section{PENDAHULUAN}

Beras merupakan makanan pokok yang paling banyak di konsumsi oleh masyarakat Indonesia. Menurut Survei Sosial Ekonomi Nasional 2009-2013 konsumsi beras di Indonesia mencapai 85.514 per kapita/tahun pada tahun 2013 [1]. Semakin bertambahnya penduduk di Indonesia, kebutuhan beras juga semakin bertambah. Namun harga beras yang beredar di pasaran terus melonjak sehingga banyak pedagang yang menjual beras dengan kualitas yang kurang baik. Sayangnya masih banyak konsumen yang belum tahu bagaimana cara membedakan beras dengan kualitas yang baik atau kualitas rendah dan mereka tidak peduli dengan beras yang mereka konsumsi. Oleh karena itu, diperlukan standar kualitas mutu yang harus ditetapkan oleh pihak gudang distributor beras.

Proses pengujian yang di tetapkan dari pihak Bulog terdapat dua tahap, yaitu uji visual dan uji laboratorium. Uji kualitas beras secara visual dapat dilihat dari keutuhan, kebersihan, dan putihnya beras [2]. Pengujian beras secara visual selama ini masih menggunakan cara manual sehingga dikhawatirkan masih terjadi kesalahan karena terbatasnya pengelihatan manusia. Oleh karena itu, diperlukan sebuah sistem untuk mengefisienkan pengujian beras secara visual.

Kualitas beras diidentifikasi dengan memanfaatkan pengolahan citra digital dan klasifikasi dengan decision tree atau pohon keputusan model Iterative Dichotomiser Tree (ID3) untuk proses identifikasi. Beras yang diuji adalah beras jenis IR64 yang beredar di pasaran. Proses pengujian kualitas beras dapat dilakukan dengan 
menggunakan citra digital, agar dapat dilakukan lebih cepat dan mudah. Data dari gambar digital beras, diakuisisi nilai putih, nilai bersih dan nilai utuhnya dengan pengolahan citra digital.

Sebelumnya, identifikasi kualitas beras sudah pernah dilakukan untuk menguji kualitas beras berdasarkan keutuhan beras oleh Ajay, et al [3]. Penelitian dilakukan untuk mengklasifikasi beras yang utuh dengan beras yang patah menggunakan metode morfologi citra. Hasilnya menunjukkan bahwa morfologi citra cukup efisien untuk mengklasifikasi beras utuh dan beras patah. Penelitian lainnya mengenai klasifikasi kualitas beras berdasarkan ciri fisik yaitu tekstur beras oleh Suminar [4] dengan ekstraksi ciri statistik menggunakan K-Nearest Neighbour (KNN). Penelitian ini menghasilkan akurasi sebesar $84,167 \%$. Penelitian lainnya oleh Somantri, et al [5] mengenai identifikasi mutu fisik beras dengan pengolahan citra dan Jaringan Syaraf Tiruan (JST). Warna beras dianalisis menggunakan model warna Red, Green, Blue (RGB) dan Hue, Saturation, Intensity (HSI) sedangkan bentuk beras dianalisis secara geometris meliputi roundness, luas, keliling dan panjangnya. Hasilnya menunjukkan bahwa pengolahan citra dan jaringan syaraf tiruan dapat mengidentifikasi mutu fisik beras secara konsisten dan lebih akurat. Penelitian mengenai metode ID3 telah dilakukan oleh Bhardwaj, et al [6] untuk menentukan keputusan untuk bermain kriket. Penelitian ini menunjukkan bahwa algoritma pohon keputusan ID3 bekerja dengan baik pada masalah klasifikasi memiliki dataset dengan nilai-nilai diskrit.

Data-data beras yang sebelumnya telah berhasil diakuisisi, kemudian diklasifikasi dengan pohon keputusan ID3. Pohon keputusan yang dihasilkan dari proses training akan dibentuk aturan-aturan yang digunakan untuk mengklasifikasi data beras yang telah diakuisisi ke dalam kualitas tertentu.

\section{METODE}

\subsection{Pengumpulan Data}

Data yang digunakan bersumber dari gudang beras di Kecamatan Gemolong, Sragen untuk jenis beras IR64 dari kualitas yang baik hingga kualitas buruk. Data yang dikumpulkan sebanyak 30 data berupa data tekstual yang digunakan sebagai data training untuk mendapatkan pohon keputusan.

Sedangkan data gambar beras yang akan diakuisisi bersumber dari kios Pasar Gemolong yang diambil dengan kamera smartphone 8 megapixel dengan mode manual. Data gambar diambil dengan rasio 1:1 berukuran $6 \times 6 \mathrm{~cm}$ dengan latar belakang berwarna hitam agar proses segmentasi atau pemisahan objek dengan latar belakang lebih mudah seperti terlihat pada Gambar 1. 


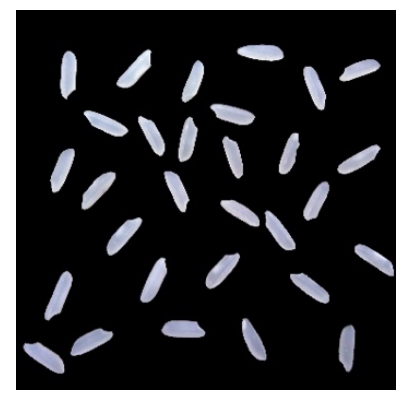

Gambar 1. Data gambar beras

\subsection{Pelatihan Data}

Tahap pelatihan dilakukan dengan metode Iterative Dichotomiser Tree (ID3) yaitu sebuah metode yang digunakan untuk membangkitkan decision tree yang mendapatkan informasi berdasarkan entropi yang merupakan sistem pengukuran statistik [7]. Pertama-tama dilakukan pengukuran jumlah informasi yang ada pada atribut yang disebut entropi. Rumus entropi dapat ditunjukkan pada persamaan (1).

$$
\operatorname{Entropy}(S)=\sum_{i=1}^{n}-p_{i} \log _{2} p_{i}
$$

Dimana $S$ adalah himpunan kasus dari suatu atribut, dan $p_{i}$ adalah probabilitas munculnya suatu kasus dari masing-masing $i$ atribut. Kemudian menghitung information gain, yaitu kriteria yang paling popular untuk pemilihan atribut. Information gain diperoleh dari persamaan (2).

$$
\operatorname{Gain}(S, A)=\operatorname{Entropy}(S)-\sum_{i=1}^{n} \frac{S_{i}}{S} \times \operatorname{Entropy}\left(S_{i}\right)
$$

Dimana $A$ adalah semua nilai yang mungkin dari suatu atribut. Setelah mendapatkan informasi dari semua atribut yang dihitung, atribut dengan information gain tertinggi dipilih sebagai atribut node awal. Proses ini terus berulang pada setiap cabang hingga terbentuk sebuah pohon keputusan.

Data tekstual yang telah dikumpulkan sebelumnya kemudian dilatih dengan metode ID3 hingga membentuk sebuah pohon keputusan. Berdasarkan pohon keputusan yang dihasilkan, diambil rules atau aturan-aturan untuk menempatkan suatu data ke dalam kelas tertentu.

\subsection{Akuisisi Data Citra Digital}

Data gambar digital beras yang telah dikumpulkan untuk tahap testing diproses menjadi data tekstual. Data yang diakuisisi adalah jumlah beras, nilai putih, nilai bersih, dan nilai utuh beras.

\subsubsection{Segmentasi Citra Biner}

Pertama dilakukan segmentasi citra biner. Tujuan segmentasi adalah mendapatkan representasi sederhana dari suatu citra sehingga lebih mudah dalam pengolahannya [8]. 
Segmentasi dilakukan dengan mengubah citra beras RGB (Red, Green, Blue) menjadi citra grayscale terlebih dahulu. Perubahan citra RGB menjadi grayscale dilakukan dengan persamaan berikut:

$$
\text { Grayscale }=\frac{R+G+B}{3}
$$

Setelah dikonversi menjadi data citra grayscale, kemudian dilakukan konversi ke citra biner dengan threshold nilai tengah dari nilai keabuan pada citra. Setelah didapatkan citra biner dilakukan segmentasi dengan memisahkan pixel berwarna hitam sebagai background dan putih sebagai objek. Untuk mempermudah analisa objek untuk tahap selanjutnya, dilakukan pengambilan data letak koordinat setiap region objek yang tersegmentasi.

\subsubsection{Akuisisi Jumlah Bulir Beras}

Pada tahap ini dilakukan pengecekan jumlah bulir beras yang akan dideteksi. Hasil segmentasi diberi label pada setiap region dengan labelling. Jumlah bulir beras didapatkan dari jumlah objek yang diberi label.

\subsubsection{Akuisisi Nilai Putih Beras}

Pada proses akuisisi nilai putih beras, dilakukan analisis nilai Hue, Saturation, dan Value. Citra awal RGB diubah ke dalam bentuk HSV untuk proses analisis. Masingmasing nilai Hue, Saturation, dan Value diambil dan dianalisis sesuai batas ambang yang ditentukan sesuai dengan standar dari gudang beras. Proses analisis dilakukan pada setiap bulir beras sesuai dengan koordinat objek segmentasi. Setelah seluruh objek dianalisis, dilakukan pelabelan nilai putih atau tidak putih. Kemudian dihitung prosentase objek yang bernilai putih. Jika jumlah bulir beras yang putih kurang dari $75 \%$ dari seluruh gambar beras, maka beras dikategorikan tidak putih.

\subsubsection{Akuisisi Nilai Bersih Beras}

Pada proses akuisisi nilai bersih beras, proses yang dilakukan untuk mendapatkan nilai bersih adalah menganalisis nilai Hue dengan batas ambang yang telah ditentukan sesuai standar dari gudang beras. Citra awal RGB diubah ke dalam bentuk HSV untuk proses analisis. Proses analisis dilakukan pada setiap bulir beras sesuai dengan koordinat objek segmentasi. Setelah seluruh objek dianalisis, dilakukan pelabelan nilai bersih atau tidak bersih. Kemudian dihitung prosentase objek yang bernilai bersih. Jika jumlah bulir beras yang bersih kurang dari $75 \%$ dari seluruh gambar beras, maka beras dikategorikan tidak bersih.

\subsubsection{Akuisisi Nilai Utuh Beras}

Pada proses akuisisi nilai keutuhan beras, dilakukan pengecekan luas daerah masingmasing objek terlebih dahulu. Penghitungan luas dilakukan dengan menghitung jumlah pixel di masing-masing region objek. Kemudian tiap objek diberi label nilai utuh atau tidak utuh. Penentuan nilai utuh beras dilakukan dengan membandingkan luas objek dengan standar luas beras yang ditentukan sesuai dengan standar dari gudang beras. Jika jumlah bulir beras yang utuh kurang dari $75 \%$ dari seluruh gambar beras, maka beras dikategorikan tidak utuh. 


\subsection{Identifikasi Kualitas Beras}

Proses identifikasi dilakukan dengan mengklasifikasi data beras ke dalam aturan-aturan berdasarkan pohon keputusan ID3 pada proses training data. Input yang digunakan untuk proses klasifikasi yaitu nilai putih, nilai bersih dan nilai utuh dari gambar beras yang telah diakuisisi sebelumnya. Output yang dihasilkan berupa hasil klasifikasi dari gambar beras ke dalam 3 kelas yaitu baik, buruk, atau kurang.

\subsection{Evaluasi Hasil Klasifikasi}

Metode yang digunakan untuk pengujian adalah $k$-fold cross validation dengan nilai $k$ $=5$. Pada metode ini data dibagi menjadi $k$ bagian secara acak, kemudian dilakukan $k$ kali eksperimen di mana masing-masing eksperimen menggunakan bagian data ke $k$ sebagai data testing dan memanfaatkan bagian lainnya sebagai data training.

Penghitungan akurasi hasil klasifikasi digunakan precision, recall, dan f-measure. Precision $(P)$ adalah jumlah klasifikasi yang bernilai benar dibagi dengan jumlah seluruh hasil klasifikasi (baik positif maupun negatif). Recall $(R)$ adalah jumlah hasil klasifikasi yang bernilai benar dibagi dengan jumlah nilai benar yang seharusnya. Sedangkan $f$-measure $(F)$ adalah nilai akurasi matriks yang menghitung rasio dari hasil yang benar dan berlaku sebagai nilai rata-rata harmonis dari precision dan recall.

$$
\begin{aligned}
& P=\frac{\text { True Positive }}{\text { True Positive }+ \text { False Positive }} \\
& R=\frac{\text { True Positive }}{\text { True Positive }+ \text { False Negative }} \\
& F=\frac{2 P R}{P+R}
\end{aligned}
$$

\section{HASIL DAN PEMBAHASAN}

\subsection{Tahap Pelatihan Data}

Data berbentuk tekstual dilatih untuk membentuk pohon keputusan. Pelatihan dilakukan dengan menggunakan software machine learning WEKA (Wakaito Environment for Knowledge Analysis). Data pelatihan disusun dengan mengkombinasikan nilai-nilai pada setiap atribut seperti terlihat pada Tabel 1.

Tabel 1. Format data pelatihan

\begin{tabular}{cccc}
\hline Bersih & Putih & Utuh & Kelas \\
\hline bersih & putih & utuh & baik \\
bersih & putih & tidak-utuh & baik \\
tidak-bersih & tidak-putih & utuh & buruk \\
tidak-bersih & tidak-putih & tidak-utuh & buruk \\
$\ldots$ & $\ldots$ & $\ldots$ & $\ldots$ \\
tidak-bersih & putih & tidak-utuh & kurang \\
\hline
\end{tabular}


Dimana kolom bersih menunjukkan nilai bersih beras, kolom putih menunjukkan nilai putih beras, kolom utuh menunjukkan nilai utuh beras, dan kolom kelas menunjukkan kelas dimana beras akan diidentifikasi.

Pelatihan ini menghasilkan sebuah pohon keputusan yang digunakan untuk membuat rules. Pohon keputusan yang dihasilkan seperti ditunjukkan pada Gambar 2.

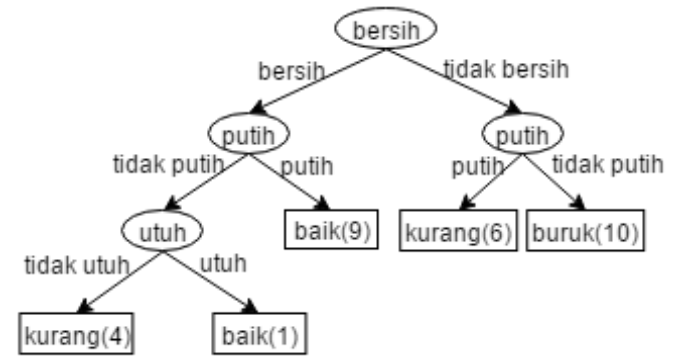

Gambar 2. Pohon keputusan

Berdasarkan pohon keputusan di atas, dapat diambil rules untuk klasifikasi yaitu:

- If bersih = bersih and putih = putih then baik

- If bersih $=$ bersih and putih $=$ tidak putih and utuh $=$ utuh then baik

- If bersih = bersih and putih = tidak putih and utuh = tidak utuh then kurang

- If bersih = tidak bersih and putih = putih then kurang

- If bersih $=$ tidak bersih and putih = tidak putih then buruk

Rules yang dihasilkan akan digunakan untuk mengklasifikasikan data ke dalam kelaskelas yang telah ditentukan.

\subsection{Segmentasi Citra Biner}

Segmentasi dilakukan dengan mengubah citra beras menjadi citra biner seperti ditunjukkan pada Gambar 3. Gambar 3(a) merupakan citra beras RGB, kemudian dilakukan konversi ke citra grayscale seperti pada Gambar 3(b). Setelah itu dilakukan konversi menjadi citra biner seperti pada Gambar 3(c). Berdasarkan citra biner yang dihasilkan kemudian dilakukan pemisahan objek dan background dengan mendeteksi warna hitam (0) dan putih (1) dengan kernel 4x4. Selain itu, juga dilakukan pengecekan data letak koordinat setiap region objek yang tersegmentasi.

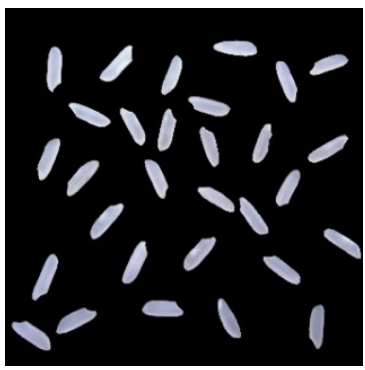

a

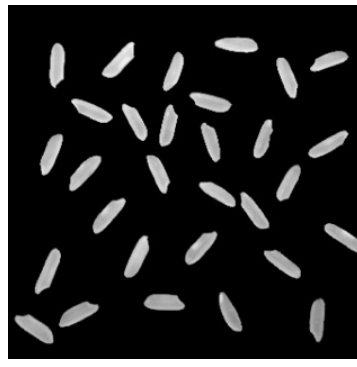

b

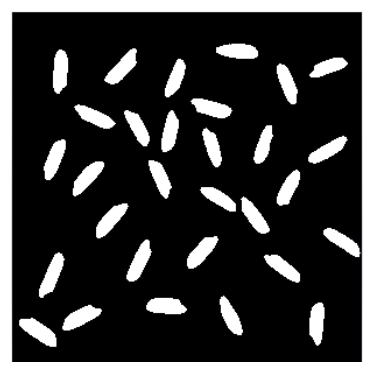

c

Gambar 3. Proses segmentasi citra biner 


\subsection{Akuisisi Jumlah Beras}

Berdasarkan hasil segmentasi, diperoleh objek dan background secara terpisah. Penghitungan jumlah dilakukan dengan cara memberi label pada setiap koordinat objek objek. Jumlah bulir beras ditentukan dari jumlah objek yang diberi label. Gambar 4(a) merupakan pelabelan pada citra tersegmentasi sedangkan Gambar 4(b) merupakan pelabelan pada citra asli sesuai dengan koordinat citra tersegmentasi. Jumlah bulir beras pada Gambar 4 yang didapatkan berjumlah 30 butir.

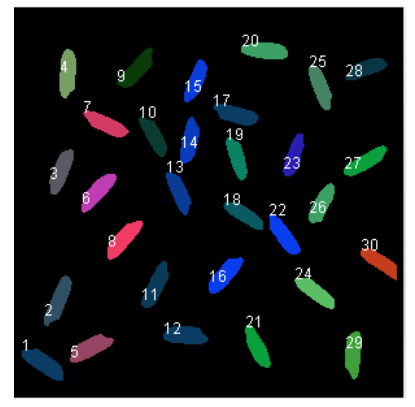

a

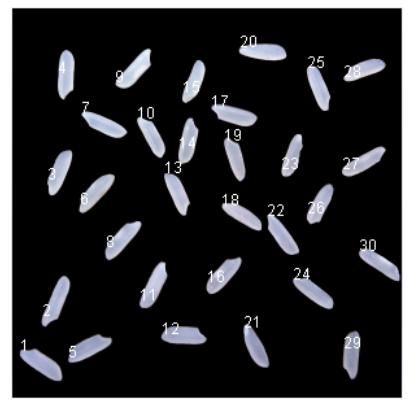

b

Gambar 4. Proses penghitungan jumlah beras

\subsection{Akuisisi Nilai Putih Beras}

Proses akuisisi nilai putih beras, dilakukan dengan menganalisis nilai Hue, Saturation, dan Value setiap objek sesuai dengan koordinat masing-masing. Agar dapat dianalisis citra RGB sebelumnya dikonversi menjadi citra HSV. Dari masing-masing objek, jika nilai Hue diantara 0.2 hingga 0.7 , nilai Saturation diantara 0.01 hingga 0.3 , dan nilai Value diantara 0.55 hingga 0.9, maka objek diberi label "putih", jika tidak maka diberi label "tidak". Gambar 5(a) merupakan citra asli yang telah diberi label, sedangkan Gambar 5(b) merupakan pelabelan hasil analisis nilai putih pada citra tersegmentasi. Jumlah beras yang terdeteksi putih pada Gambar 5 adalah sebanyak 28 butir. Jadi prosentase nilai putih pada Gambar 5 adalah $86 \%$.

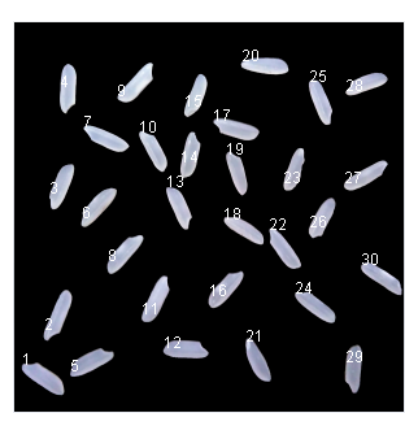

a

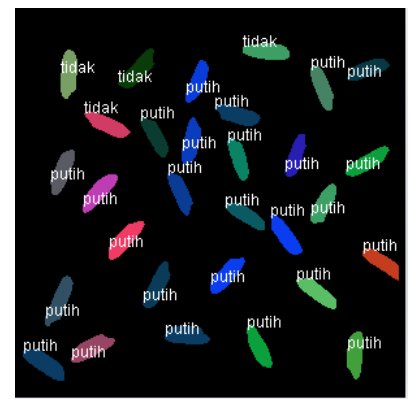

b

Gambar 5. Proses pengambilan nilai putih 


\subsection{Akuisisi Nilai Bersih Beras}

Proses akuisisi nilai putih beras, dilakukan dengan menganalisis nilai Hue untuk setiap objek sesuai dengan koordinat masing-masing. Agar dapat dianalisis citra RGB sebelumnya dikonversi menjadi citra HSV. Dari masing-masing objek, jika nilai Saturation $<0.4$ dan nilai Value $>0.55$, maka objek diberi label "bersih", jika tidak maka diberi label "tidak". Gambar 6(a) merupakan citra asli yang telah diberi label, sedangkan Gambar 6(b) merupakan pelabelan hasil analisis nilai bersih pada citra tersegmentasi. Jumlah beras yang terdeteksi bersih pada Gambar 6 adalah sebanyak 30 butir. Jadi prosentase nilai bersih pada Gambar 6 adalah 100\%.

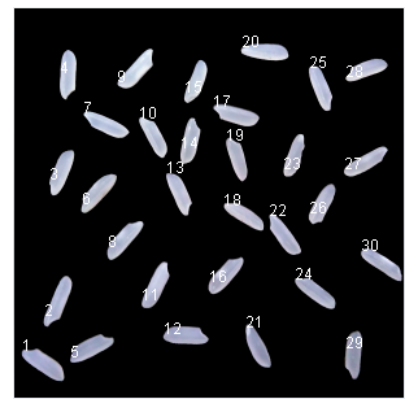

a

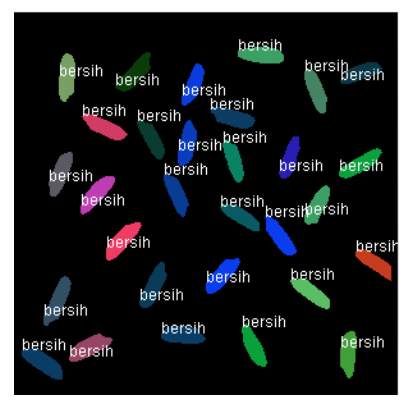

b

Gambar 6. Proses pengambilan nilai bersih

\subsection{Akuisisi Nilai Utuh Beras}

Pada proses akuisisi nilai utuh beras, dilakukan pengecekan luas daerah masing-masing objek terlebih dahulu. Penghitungan luas dilakukan dengan menghitung jumlah pixel di masing-masing region objek. Penentuan nilai utuh beras dilakukan dengan membandingkan luas objek dengan standar luas beras yang ditentukan sesuai dengan standar dari gudang beras. Jika luas $\geq 60 \%$ dari standar, maka beras diberi label "ya", jika tidak maka diberi label "tidak". Gambar 7(a) merupakan citra asli yang telah diberi label, sedangkan Gambar 7(b) merupakan pelabelan hasil analisis nilai bersih pada citra tersegmentasi. Jumlah beras yang terdeteksi utuh pada Gambar 7 adalah sebanyak 30 butir. Jadi prosentase nilai utuh pada Gambar 7 adalah 100\%.

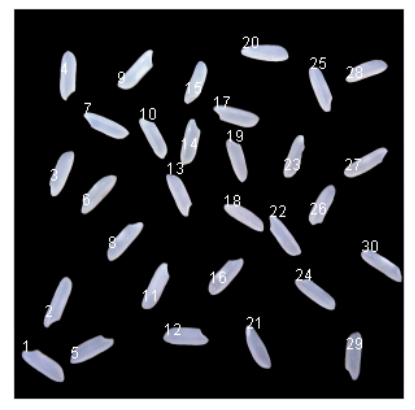

a

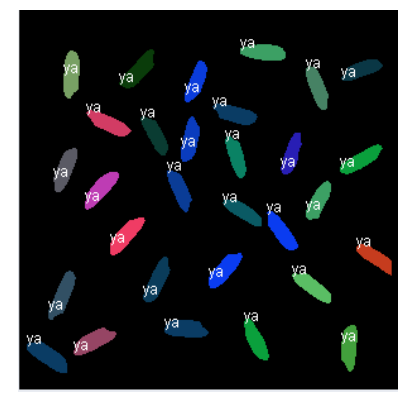

b

Gambar 7. Proses pengambilan nilai utuh 


\subsection{Identifikasi Kualitas Beras}

Berdasarkan hasil akuisisi citra, kemudian dilakukan klasifikasi untuk mengidentifikasi kualitas beras yang diuji. Klasifikasi dilakukan dengan menganalisa data tekstual dari hasil akuisisi citra menggunakan rules yang didapatkan dari pohon keputusan pada Gambar 2. Data citra yang diklasifikasi sejumlah dan sesuai dengan data tekstual yang digunakan pada proses pelatihan.

Sebagai contoh, digunakan Gambar 5, Gambar 6 dan Gambar 7 pada tahap akuisisi citra sebelumnya, hasil identifikasi kualitas beras menggunakan klasifikasi ID3 ditunjukkan pada Tabel 2.

Tabel 2. Contoh hasil klasifikasi

\begin{tabular}{cccccc}
\hline Data Gambar & $\begin{array}{c}\text { Nilai } \\
\text { Putih }\end{array}$ & $\begin{array}{c}\text { Nilai } \\
\text { Bersih }\end{array}$ & $\begin{array}{c}\text { Nilai } \\
\text { Utuh }\end{array}$ & Kelas & Kesesuaian \\
\hline & & & & & \\
& & & & & \\
$(86 \%)$ & $(100 \%)$ & $(100 \%)$ & & & \\
\hline
\end{tabular}

Hasil identifikasi dari Gambar 5, Gambar 6, dan Gambar 7 adalah beras berkualitas baik. Dari 30 data yang diuji, hasil menunjukkan 29 data terklasifikasi sesuai dengan pelatihan.

\subsection{Evaluasi Hasil Klasifikasi}

Berdasarkan hasil klasifikasi data, dilakukan evaluasi terhadap keakurasian data yang diklasifikasikan $k$-fold cross validation dengan nilai $k=5$. Hasil evaluasi ditunjukkan pada Tabel 3.

Tabel 3. Hasil Pengujian

\begin{tabular}{cccc}
\hline Kelas & \multicolumn{3}{c}{ Kelas hasil pengujian } \\
\cline { 2 - 4 } sebenarnya & Baik & Kurang & Buruk \\
\hline Baik & 9 & 1 & 0 \\
\hline Kurang & 0 & 10 & 0 \\
\hline Buruk & 0 & 0 & 10 \\
\hline
\end{tabular}

Hasil klasifikasi kemudian dihitung keakurasiannya dengan menghitung precision $(P)$, recall $(R)$, dan $f$-measure $(F)$.

$$
\begin{gathered}
P=\frac{29}{29+1}=0.97 \\
R=\frac{29}{29+1}=0.97 \\
F=\frac{2 \times 0.97 \times 0,97}{0.97+0.97}=0,97
\end{gathered}
$$




\section{SIMPULAN}

Identifikasi kualitas beras dengan citra digital menggunakan klasifikasi ID3, didapatkan hasil akurasi sebesar $96.67 \%$ dimana hanya 1 dari 30 data diklasifikasikan tidak sesuai dengan hasil yang sebenarnya. Hasil akurasi klasifikasi yang didapatkan dengan metode $k$-fold cross validation dengan $k=5$ juga cukup akurat yakni precision 0.97 , recall 0.97 , dan f-measure 0.97. Dari pemaparan tersebut dapat disimpulkan bahwa pengolahan citra digital dapat dimanfaatkan untuk melakukan identifikasi kualitas beras dengan metode klasifikasi decision tree ID3.

\section{REFERENSI}

[1] Kementrian Pertanian RI. 2013. Konsumsi Rata-rata per Kapita Setahun Beberapa Bahan Makanan di Indonesia, 2009-2013. http://www.pertanian .go.id/Indikator/tabe-15b-konsumsi-rata.pdf, diakses 10 April 2015.

[2] Beras Indonesia. 2014. Produk dan Standar Mutu. http://www.beras indonesia.com/kualitas_produk, disakses 15 Mei 2014.

[3] Ajay, G., Suneel, M., Kumar, K. K., dan Prasad, P. S. 2013. Quality Evaluation of Rice Using Morphological Method. International Journal of Soft Computing and Engineering (IJSCE). Vol. 2(6): 35-37.

[4] Suminar, R., Hidayat, B., dan Atmaja, R. D. 2012. Klasifikasi Kualitas Beras Berdasarkan Ciri Fisik Berbasis Pengolahan Citra Digital. Jurnal Telkom University.

[5] Somantri, A. S., Darmawati, E. dan Astika, I. W. 2013. Identifikasi Mutu Fisik Beras dengan Menggunakan Teknologi Pengolahan Citra dan Jaringan Syaraf Tiruan. Jurnal Pascapanen. Vol. 10(2): 95-103.

[6] Bhardwaj, R., dan Vatta, S. 2013. Implementation of ID3 Algorithm. International Journal of Advanced Research. Vol. 3(6): 856-861.

[7] Aradeo, S. A., Ariyan, Z. dan Yuliana, A. 2011. Penerapan Decision Tree untuk Penentuan Pola Data Penerimaan Mahasiswa Baru. Jurnal Penelitian Sitrotika. Vol. 7(1).

[8] Putranto, B. Y. B., Hapsari, W. dan Wijana, K. 2010. Segmentasi Warna Citra dengan Deteksi Warna HSV untuk mendeteksi Objek. Jurnal Informatika. Vol. 6(2): 1-14. 